\title{
DATOVÉ STRUKTURY PRO ÚČELY LCA S VYUŽITÍM BIM: REŠERŠE A TEORETICKÁ VÝCHODISKA
}

\section{A DATA STRUCTURES FOR PURPOSE OF THE BIM-BASED LIFE CYCLE ASSESSMENT: A REVIEW AND THEORETICAL BACKGROUND}

\author{
Ing. Michal Brandtner ${ }^{1 *}$; Ing. Adam Boháček ${ }^{1}$ \\ ${ }^{1}$ Vysoké učení technické v Brně, Fakulta stavební, Veveři 331/95, 60200 Brno, Česká republika \\ *korespondenční autor: 159111@vutbr.cz
}

\section{ABSTRAKT CZ}

Stavebnictví produkuje výrazné množství odpadů a zároveň se naplňují kapacity skládek. Je nutné se zabývat efektivním využitím již použitých materiálů, které mají potenciál být znovu využity. Posuzování životního cyklu (Life Cycle Assessment - LCA) je metoda posuzování životního cyklu produktu nebo služby z hlediska jeho působení na životní prostředí. Informační model budovy (BIM) obsahuje kromě geometrie i informační část, kterou je možné využít pro toto posouzení. Tyto data můžou být použita pro inventuru životního cyklu (LCI) a poté pro samotné hodnocení. Cílem článku je analyzovat předchozí př́stupy a definovat, jakou datovou strukturu je nutné získat z BIM modelu pro účely LCI konkrétního materiálu. Navrhovaná metodika je postavena na základě informací z datové struktury standardizace negrafických informací modelu, zvaná (SNIM), která byla vyvinuta pro prostředí České republiky.

Klíčová slova: Stavebnictví, Metoda LCA, BIM model, 3D model, studie $L C A, L C l$, české prostředí, SNIM

\begin{abstract}
Construction industry produces a significant amount of waste and on the other hand the capacities of landfills are almost filled. It is necessary to deal with the effective use of materials that have already been used and have potential to be reused again. Life Cycle Assessment (LCA) is a method of assessing the life cycle of a product or service in terms of its environmental impact. The Building Information Model (BIM) includes, in addition to geometry, the information part. This data can be used for life cycle inventory (LCI) and then for the assessment itself. The aim of the article is to analyse previous approaches and define which data structure is necessary to be obtained from the BIM model for the LCI purpose of a specific material. The proposed methodology of the data recognition and selection is based on data structure of non-graphical database called SNIM, which was developed for the Czech construction environment.
\end{abstract}

Key words: Construction industry, the LCA methodology, the BIM model, 3D model, LCA study, life cycle inventory (LCI), Czech environment, SNIM

\section{1 ÚVOD}

Problematika posuzování životního cyklu stavebních výrobků je aktuální téma v souvislosti s požadavkem na udržitelnou výstavbu, který vychází ze Směrnice Evropského parlamentu a Evropské 
komise č. 305/2011 [1]. Nový požadavek na stavební výrobky ale i na celá stavební díla spočívá v udržitelném využívání přírodních zdrojů pro zajištění šetrnosti budov k životnímu prostředí. Udržitelné využívání př́rodních zdrojů souvisí s možností opětovného využití či recyklace použitých materiálů pro výstavbu, ale i recyklovanost celých staveb či použití materiálů a surovin šetrných k životnímu prostředí již během výstavby. Jedním způsobem posouzení tohoto nového požadavku je právě metoda Life Cycle Assessment (LCA) [2].

Posuzování životního cyklu zanglického LCA je metoda analytická založená na hodnocení environmentálních dopadů na životní prostředí výrobků, služeb či technologií. Kočí [2] popisuje př́stup metody LCA k hodnocení environmentálních dopadů na životní prostředí s ohledem na celý životní cyklus produktů, tj. od stádia získávání a výroby prvotních materiálů přes stádium výroby produktů, jejich uživání až po samotné odstranění či opětovné využití produktů v podobě recyklace.

V minulosti byl popsán využívaný způsob získávání dat pro posuzování životního cyklu nejrůznějších produkti̊. Autoři se věnovali popisu dat vstupujících do LCA. Článek je zaměřen na shrnutí minulých, současných ale i předpokládaných budoucích způsobů, jakými se budou data pro posuzování LCA získávat. Dále je má článek za cíl stanovit, jakým způsobem budou tříděny informace z databáze SNIM pro aplikaci do studie LCA.

\section{SOUČASNÝ STAV ŘEŠENÉ PROBLEMATIKY}

V roce 1990 se poprvé objevuje komplexní environmentální analýza zátěží a modely plnohodnotného hodnocení životního cyklu a kalkulace životního cyklu. Začátkem 21 . století byl vytvořen program Life Cycle Initiative, jehož cílem bylo praktikovat myšlenky životního cyklu do praxe. [3]

Propojením metody LCA s možností využití datové struktury BIM modelu se již zabývalo mnoho autorů. Antón [4] v závěru článku představila dva př́ístupy integrace mezi LCA a BIM. Jeden z nich je posouzení celého životního cyklu konstrukce a druhý př́stup je materiálově orientovaný. Autoři v dalším článku [5] hodnotí nejnovější studie, které jsou zaměřeny na LCA založeného na BIM. Zároveň se soustředí na to, jak by BIM mohlo přispět ke zjednodušení zadávání dat, k optimalizaci výstupu dat a výsledků během aplikace LCA v konkrétních budovách.

Finnveden ve svém článku [6] popisuje vývoj LCA. Tento článek poskytuje přehled o nedávném vývoji LCA. Autoři diskutují o oblastech, kde došlo k pokroku. Mezi tyto oblasti můžeme zahrnout: rozdíl mezi atributní a následnou LCA, hybridním vývojem LCA databáze a kategorie dopadů (jako je prostorová diferenciace, toxicita, znečištění ovzduší ve vnitřním prostředí a dopady z využívání půdy, zdrojů a vody). Autoři ukazují největší úspěchy. $V$ dnešní době bychom měli být schopni lépe porozumět rozdíl mezi atributní a následnou LCA a také metodami pro hybridní IOA-LCA. Autoři však zdůrazňují, že existuje mnoho oblastí, na něž se můžeme zaměřit. Mezi tyto oblasti patř́́: vývoj nástrojů pro LCA, metody hodnocení dopadů využívání půdy a využívání vody na ekosystémy. Hlavní oblastí rozvoje by měly být databáze.

Další článek o LCA [7] shrnuje veškerý výzkum hodnocení životního cyklu, který byl aplikován ve stavebnictví. Autoři říkají, že více než kdy dříve se stavebnictví zabývá zlepšením sociálních, ekonomických a př́rodních indikátorů udržitelnosti. Pokud bychom více používali metodu LCA, tak je možné dosáhnout lepší optimalizace těchto aspektů a tím i lépe kontrolovat životní cyklus budovy (od těžby přírodních surovin až po konečné odvezení stavebních materiálů na skládku). Můžeme tedy říci, že se autoři snaží zanalyzovat dřivější výzkum LCA a srovnat jej se současným výzkumem LCA a tím vypíchnout hlavní výzvy pro vývoj LCA a stavebnictví. Studie tedy poskytuje základní charakteristiku LCA a její metodologie. Dále se zabývá cestami a rozdíly využití LCA u stavebních materiálů a doi.org/10.51704/cjce.2020.vol6.iss2.pp21-27 
kombinací komponentů (BMCC) proti využití LCA u celého stavebního procesu (WPC). Studie jen potvrzuje, že LCA je velice inovativní metodou, která zlepšuje udržitelnost životnosti budovy skrz všechny její fáze.

Marzouk [8] ve své studii popisuje spojení LCA s BIM. Tato studie nám představuje BIM, který umožňuje odhadnout 6 typů emisí. Zahrnujeme sem skleníkový efekt, oxid siřičitý, různé částice, částice eutrofizace, částice poškozující ozon a smog. Díky tomuto nástroji je možné vypočítat produkci př́mých a nepřímých emisí během celého stavebního procesu, tedy od výrobní fáze přes fázi přepravy, stavební fázi, provozní fázi, fázi údržby až po fázi demolice. Pro výpočty používali autoři aplikaci Athena Impact Estimator a Autodesk Revit.

Autoři dalšího článku [9] přichází s metodou automatických výpočtů LCA v rané fázi, tedy již na první úrovni podrobnosti BIM (LOD100). To by mělo vést $\mathrm{k}$ lehčím úpravám výpočtů během dalšího vývoje BIM modelu. K tomu, abychom tohoto cíle dosáhli, je potřeba nových vrstev dat a jejich formátů. Tato nová datová vrstva by měla vyplnit informační mezery mezi extrahovanými daty BIM a stávajícími daty LCA poskytovanými běžnými databázemi LCA. Výsledkem tohoto článku je tedy přiblížení této metody. Dalším krokem je otestování této metody v budoucích vědeckých pracích.

Další článek [10] se týká integrace dopadů na životní prostř̌edí v rámci BIM. Druhotným cílem je najít řešení, jak by mohli projektanti zmírnit tyto environmentální dopady. Autoři navrhli BIM-integrované hodnocení a také vizualizaci dopadů na životní prostředí. Výsledky ukazují, že by bylo možné tímto př́stupem říci, jaké environmentální dopady bude mít stavební materiál v počátečních fázích návrhu. Vizualizace geometrického modelu budovy může být použita jako reprezentace návrhu, který může vést k lepšímu rozhodnutí o materiálových volbách pro jednotlivé stavební prvky.

Efektivnost analýzy životního cyklu je řešena v dalším článku [11]. Autoři tohoto článku se zabývají propojením mezi nástrojem založeným na nástroji BIM a nástroji LCA (Gabi 6). V článku bylo prokázáno, že modul plug-in BIM může poskytnout potřebná data pro každou fázi návrhu. To znamená, že návrhář může provádět plnou analýzu životního cyklu efektivněji.

Na základě výše uvedených referencí lze říci, že autoři se již v minulosti zabývali možností propojení studií LCA s informacemi obsaženými v 3D modelu v prostředí BIM. Autoři ve svých publikacích využívali rozdělení stádií životního cyklu produktů pomocí kategorií dopadů a rovněž zvolenou metodiku pro výpočty studií LCA ověřovali pomocí různých softwarových nástrojů jako Autodesk Revit, Gabi 6, apod.

\section{TEORETICKÁ VÝCHODISKA}

\subsection{Produkt a jeho stádia dopadů na životní prostředí}

Autor Kočí ve své publikaci popisuje životní cyklus produktů, který má různé dopady na životní prostředí, ve čtyřech hlavních stádiích. První stádium získávání surovin pro výrobu potřebných materiálů pro výrobu produktu zahrnuje těžbu ropy, železný rud či dřeva a jejich dopravu z místa, kde jsou získávány, do místa dalšího zpracování. Druhé stádium popisuje výrobu produktu z již získaných materiálů a surovin v prvním stádiu. Stádium zahrnuje přeměňování získaných surovin na materiály, které jsou použitelné v další průmyslové výrobě. Přeměňování surovin však zahrnuje např́iklad spotřebu elektrické energie či různých paliv. Třetí stádium užívání produktu zahrnuje spotřebu produktu či jeho využití pro funkci, ke které byl vyroben. Nedílnou součástí tohoto stádia jsou opět energetické a surovinové požadavky, které budou sloužit pro samotný provoz produktu, jeho př́padné opravy, 
uskladnění či údržbu. Čtvrté, poslední stádium popisuje již závěrečné odstranění produktu včetně energetických a materiálových nároků na odstranění produktu či př́ípadně jeho recyklaci. [2]

\subsection{Posuzování dopadů životního cyklu pomocí kategorií dopadu na životní prostředí}

Životní cyklus produktů a hodnocení jejich dopadu na životní prostředí pomocí tzv. kategorií dopadu autor dále dělí na šest konkrétních oblastí. Jedná se o Globální oteplování a klimatické změny, úbytek stratosférického ozonu, acidifikaci, eutrofizaci, vznik fotooxidantů a úbytek surovin. Každá kategorie dopadu zahrnuje procesy a důsledky, jakými je negativně ovlivňováno životní prostředí. Globální oteplování zahrnuje zvyšování průměrné teploty atmosféry vlivem zachycování většího množství energie $\mathrm{v}$ atmosfére, které vede ke klimatickým změnám na globální úrovni či k tzv. skleníkovému jevu. Úbytek stratosférického ozonu vede k pronikání většího množství UV záření na zemský povrch, což vede k nepříznivému ovlivnění zdraví člověka či kvality životního prostředí. Acidifikace je proces okyselování půdního nebo vodního prostředí způsobený vypouštění kyselinotvorných látek do atmosféry, vody a půdy. Okyselené srážky kondenzují na pevných površích či se rozpouštějí ve vodě, což vede k okyselování půdy, vody a stavebních materiáli̊. Zmíněné látky jsou škodlivé také pro rostliny a stromy. Eutrofizace souvisí s obohacováním prostředí živinami, což vede k zarůstání povrchových vod, k nedostatku kyslíku ve vodách či ke zhoršení kvality zdrojů pitné vody. Vznik fotooxidantů zahrnuje nepříznivé působení ozonu či jiných látek v přízemní vrstvě atmosféry, což vede k negativnímu vlivu na životní prostředí v podobě vzniku různých nemocí a ovlivňování zdraví živých organismů. Úbytek surovin je spojen s nadměrnou těžbou neobnovitelných zdrojů člověkem, což vede k narušování ekosystémů a k ovlivnění množství surovin dostupných v budoucnosti. [2]

\subsection{Standardizace negrafických informací 3D modelu (SNIM)}

Standardizace negrafických informací 3D modelu je soubor informací a standardů, které byly vyvinuty zejména pro projektování s využitím BIM modelu v prostředí České republiky. K jednotlivým prvkưm 3D modelu byly přiřazeny parametry (negrafické informace), které jsou dále rozděleny dle požadavků pro jednotlivé stupně projektové dokumentaci v souvislosti s danou fází výstavby. SNIM obsahuje seznam parametrů, které jsou prriřazeny ke konkrétním konstrukcím a třídník stavebních konstrukcí, který jednotlivé typy konstrukcí rozděluje dle technických a parametrických informací. Tř́dník stavebních konstrukcí byl vytvořen $\mathrm{z}$ důvodu snahy o lepší orientaci v projektu za pomocí databázového vyhledávání.

\section{METODY}

V souvislosti s využíváním informací z prostředí BIM, vznikla, zejména pro prostředí České republiky, databáze standardů a parametrů, sloužící pro stavebně inženýrskou činnost v prostředí BIM. Zmíněné parametry neboli negrafické informace, byly autory roztř́iěny dle nově vytvořeného třídníku stavebních konstrukcí a přiřazeny $\mathrm{k}$ jednotlivým prvkům $3 \mathrm{D}$ modelu v prostředí BIM. Součástí třídníku je rovněž doporučený formát a podoba zadáváni jednotlivých informací. Jedná se o takzvanou standardizaci negrafických informací modelu. [12]

V souvislosti s novým zaváděním prostředí BIM pro stavebnictví v České republice je možné využití roztř́iděných informací z tohoto prostředí pro možnost zjednodušení výpočtů studií LCA. Tato nová metoda využivá poznatků o stádiích životního cyklu produktů v souvislosti s možnými dopady na životní prostředí. Dále je uvažováno s rozdělením kategorií dopadu na šest konkrétních oblastí. Data roztříděná 
dle parametrů přiřazených jednotlivým prvkům 3D modelu v prostředí BIM databáze SNIM budou pro možnost využití pro výpočty LCA dále vybírána s třízena dle přesně stanovených kritérií.

Pro posouzení životního cyklu produktů s možností hodnocení jejich dopadu na životní prostředí metodou LCA je potřeba stanovit hodnoty jednotlivých indikátorů kategorií dopadu s ohledem na jednotlivá stádia životního cyklu produktů. Tyto hodnoty, tvořící soubor výsledků, musí mít kromě konkrétních hodnot, také jednoznačně definovány jednotky. Jednotlivé soubory výsledků jsou poté přiřazeny do konkrétních druhů kategorií dopadu, které mají různé vlivy na životní prostředí. V grafické a informační části BIM modelu stavebního díla jsou jednoznačně definovány parametry, které je možno využít pro hodnocení LCA. V souvislosti se standardizací negrafických informací modelu a se vznikem již zmíněných standardů a parametrů se nabízí možnost doplnění BIM modelu o konkrétní informace ze SNIM pro komplexní posouzení stavebního díla z hlediska jeho celého životního cyklu.

\subsection{Metodika výběru dat z prostředí SNIM pro účely LCI}

Při výběru dat z prostředí SNIM budou využita data v úrovni podrobnosti studie. Důvodem je dostatečné množství informací v této fázi výstavby pro základní účely LCI a také snaha zabývat se co nejvíce reálnou situací. Ve stavební praxi jsou ve fázi studie sice dostupné pouze některé informace, ale i tak již v této fázi výstavby narůstá snaha o předběžný výpočet studií LCA na základě LCI pro snížení dopadu na životní prostředí plánované stavby.

Uvažovaná medika vychází z možnosti, že z databáze SNIM budou převzaty objemy jednotlivých konstrukcí a také data, která obsahují značení konstrukcí. Společně se jedná o data, která obsahují název daného prvku, jeho objem, značení dle SNIM, specifikaci či další konkrétní popis. Tato data budou použita pro účely základní struktury LCI (studie LCA). Příklad vzhledu datové struktury pro jednu kategorii materiálu je uveden $v$ tabulce 1 .

\begin{tabular}{|c|c|c|c|c|c|}
\hline & $\begin{array}{c}\text { Značení dle } \\
\text { SNIM }\end{array}$ & Podkategorie & Popis & MIN & MAX \\
\hline Typ konstrukce & XX000 & Specifikace konstrukce & $\cdots$ & 000 & 000 \\
\hline
\end{tabular}

Tab. 1 Př́íklad vzhledu datové struktury pro jednu kategorii materiálu.

Bohužel však data převzatá z databáze SNIM neobsahují indikátory kategorií dopadu (emise). Tato data tudíž musí být $\mathrm{k}$ výpočtu přiřazena $\mathrm{z}$ externích zdrojů, jako jsou již existující databáze či konkrétní data zjištěná př́mo od výrobců daného materiálu.

Na základě specifikace je možné ke každému konkrétnímu materiálu přiřadit konkrétní hodnotu LCI. Přiřazená hodnota LCI ke konkrétnímu materiálu je vždy pouze pro jednu základní jednotku množství daného materiálu ( $\mathrm{tj} . \mathrm{m}^{3}, \mathrm{~m}^{2}, \mathrm{~m}$, tuna apod.). $\mathrm{Z}$ toho důvodu následně dojde $\mathrm{k}$ vynásobení hodnoty LCI hodnotou objemu daného prvku. Na základě těchto informací bude pomocí maticového řešitele Matlab vygenerována konkrétní hodnota LCI všech materiálu každého prvku v konkrétní konstrukci. Závěrem je procentuální rozložení jednotlivých emisních faktorů např́ič celkovou materiálovou charakteristikou ve stavbě.

\section{ZÁVĚR}

Na závěr nutno říci, že navrženou metodiku je třeba ověřit na dostatečném množství případových studií konkrétních objektů. Toto ověření bude předmětem dalšího výzkumu dané problematiky. Článek měl za cíl shrnout teorii, současný stav řešené problematiky a také nastínit rámcový postup, jakým je možné $\mathrm{v}$ budoucnu přistupovat při výpočtech environmentálních dopadů. $\mathrm{V}$ další fázi výzkumu bude možné doi.org/10.51704/cice.2020.vol6.iss2.pp21-27 
zvolit konkrétní př́padovou studii, jejíž výsledky budou porovnány s již prezentovanými výsledky jiných autorů, a to s využitím nejrůznějších software a parametrů. V budoucnu by bylo rovněž vhodné vytvořit specializovaný software, zabývající se výpočty LCA a LCI či vývoj plug-in pro české prostředí, který bude snadno využitelný ve stavební praxi.

\section{Poděkování}

Příspěvek vznikl za podpory Standardního specifického výzkumu Vysokého učení technického v Brně s registračním číslem FAST-S-20-6338 a Juniorského specifického výzkumu s registračním číslem FAST-J-20-6359. 


\section{Použitá literatura}

[1] REGULATION (EU) No 305/2011 OF THE EUROPEAN PARLIAMENT AND OF THE COUNCIL: laying down harmonized conditions for the marketing of construction products and repealing Council Directive 89/106/EEC. In: Strasbourg: European Council, 2011, ročník 2011, 305/2011.

[2] KOČÍ, Vladimír. LCA a EPD stavebních výrobki̊: posuzování životního cyklu a environmentální prohlášení o produktu jako cesta $k$ udržitelnému stavebnictví. Praha: Česká rada pro šetrné budovy, 2012. ISBN 978-80-260-3504-6.

[3] Jeroen B. Guinée et all. Life Cycle Assessment: Past, Present, and Future. Environ. Sci. Technol., 2011, 45, 90-96. DOI: 10.1021/es101316v.

[4] ANTÓN, Laura Álvarez a Joaquín DÍAZ. Integration of Life Cycle Assessment in a BIM Environment. Procedia Engineering. 2014, 85, 26-32. DOI: 10.1016/j.proeng.2014.10.525. ISSN 18777058

[5] SOUST-VERDAGUER, Bernardette, Carmen LLATAS a Antonio GARCÍA-MARTÍNEZ. Critical review of bim-based LCA method to buildings. Energy and Buildings. 2017, 136, 110 120. DOI: 10.1016/j.enbuild.2016.12.009. ISSN 03787788. Dostupné také z: https://linkinghub.elsevier.com/retrieve/pii/S0378778816317650

[6] 011. FINNVEDEN, Göran, Michael Z. HAUSCHILD, Tomas EKVALL, et al. Recent developments in Life Cycle Assessment. Journal of Environmental Management. 2009, 91(1), 1-21. DOI: 10.1016/j.jenvman.2009.06.018. ISSN 03014797. Dostupné také z: https://linkinghub.elsevier.com/retrieve/pii/S0301479709002345

[7] ORTIZ, Oscar, Francesc CASTELLS a Guido SONNEMANN. Sustainability in the construction industry: A review of recent developments based on LCA. Construction and Building Materials. 2009, 23(1), 28-39. DOI: 10.1016/j.conbuildmat.2007.11.012. ISSN 09500618.Dostupné také z: https://linkinghub.elsevier.com/retrieve/pii/S0950061807003005

[8] MARZOUK, Mohamed, Eslam Mohammed ABDELKADER a Khalid AL-GAHTANI. Building information modeling-based model for calculating direct and indirect emissions in construction projects. Journal of Cleaner Production. 2017, 152, 351-363. DOI: 10.1016/j.jclepro.2017.03.138. ISSN 09596526. Dostupné také z: https://linkinghub.elsevier.com/retrieve/pii/S0959652617305905

[9] DUPUIS, M., A. APRIL, P. LESAGE a D. FORGUES. Method to Enable LCA Analysis through Each Level of Development of a BIM Model. Procedia Engineering. 2017, 196, 857863. DOI: 10.1016/j.proeng.2017.08.017. ISSN 18777058. Dostupné také z: https://linkinghub.elsevier.com/retrieve/pii/S1877705817331375

[10] RÖCK, Martin, Alexander HOLLBERG, Guillaume HABERT a Alexander PASSER. LCA and BIM: Visualization of environmental potentials in building construction at early design stages. Building and Environment. 2018, 140, 153-161. DOI: 10.1016/j.buildenv.2018.05.006. ISSN 03601323. Dostupné z: https://linkinghub.elsevier.com/retrieve/pii/S036013231830266X

[11] BUENO, Cristiane a Márcio Minto FABRICIO. Comparative analysis between a complete LCA study and results from a BIM-LCA plug-in. Automation in Construction. 2018, 90, 188-200. DOI: 10.1016/j.autcon.2018.02.028. ISSN 09265805. Dostupné také z: https://linkinghub.elsevier.com/retrieve/pii/S0926580518301249

[12] Standardizace negrafických informací 3D modelu [online]. [cit. 2019-03-03]. Dostupné z: http://www.czbim.org/nodes/nodes/view/type:stranka/slug:standardizace-negrafickychinformaci-3d-modelu 